This is a post-referring version of a paper published as:

\title{
Challenging the moral status of blood donation
}

Snelling, P. C. (2014). Challenging the moral status of blood donation. Health Care Analysis, 22(4), 340-365.

The published version is available at https://link.springer.com/article/10.1007/s10728-012-0221-4

\begin{abstract}
Abstract The World Health Organisation encourages that blood donation becomes voluntary and unremunerated, a system already operated in the UK. Drawing on public documents and videos, this paper argues that blood donation is regarded and presented as altruistic and supererogatory. In advertisements, donation is presented as something undertaken for the benefit of others, a matter attracting considerable gratitude from recipients and the collecting organisation. It is argued that regarding blood donation as an act of supererogation is wrongheaded, and an alternative account of blood donation as moral obligation is presented. Two arguments are offered in support of this position. First, the principle of beneficence, understood in a broad consequentialist framework obliges donation where the benefit to the recipient is large and the cost to the donor relatively small. This argument can be applied, with differing levels of normativity, to various acts of donation. Second, the wrongness of free riding requires individuals to contribute to collective systems from which they benefit. Alone and in combination these arguments present moral reasons for donation, recognised in communication strategies elsewhere. Research is required to evaluate the potential effects on donation of a campaign which presents blood donation as moral obligation, but of wider importance is the recognition that other-regarding considerations in relation to our own as well as others' health result in a range not only of choices but also of obligations.
\end{abstract}

\section{Keywords}

Blood donation, Organ donation, Altruism, Obligation, Television advertisements

Dr Paul Snelling

Principal Lecturer in adult nursing

Department of Nursing and Midwifery

University of Worcester

Henwick Grove

Worcester

WR2 6AJ

용 01905542615

p.snelling@worc.ac.uk 


\section{Introduction}

It is a commonplace that health, variously understood, is a good thing and that work to protect, maintain and restore it is therefore also good. The responsibility, that is the obligation, to meet the demands this principle requires falls to a number of individuals and organisations. In the UK, despite the discourse of 'personal responsibility' for health, moral, legal, and professional obligations to patients and the public rest principally with health professionals within socialised medicine. Where the notion of personal responsibility is referred to it is predominantly directed at individuals' own health, offering self and otherregarding reasons for action. Self-regarding reasons take the form, to borrow Kantian terminology, of hypothetical imperatives; if you want to be healthy, you ought to undertake this action (or omit that action). Categorical imperatives are seen where reasons to protect an individual's health are other-regarding, seen for example in health promotion messages which emphasise harm to others, commonly children, that ill health or early death of the individual brings ${ }^{1}$. Outside caring and professional relationships, the notion of legal and moral responsibility for others' health is rarely seen ${ }^{2}$, and where it is, it requires omissions. Legislation to ban smoking in public places was justified in order to protect the health of others (Ferguson 2011) , $^{3}$ recklessly infecting someone with HIV is a criminal offence ${ }^{4}$ (Bennett 2007), and more mundanely, patients are exhorted not to attend GP surgeries if they think that they are infected with swine flu. ${ }^{5}$

The question of moral responsibility to act for other's health is seldom addressed and I shall use the example of blood donation to argue that this responsibility is plausible in certain circumstances. Within the broader category of tissue and organ donation, it is possible further to distinguish types of acts and their moral statuses, from the obligatory to the supererogatory, and though the rule of rescue (McKie and Richardson 2003) and family responsibilities apply and complicate in some instances of donation, they are seldom seen in one of the commonest donation acts: blood donation. Using publically available documents and communications material, this paper both analyses the moral status presented and offers an alternative normative account. I argue that hitherto, blood donation has been regarded in the UK and elsewhere as altruistic and supererogatory. I suggest that this position is wrongheaded, and instead that blood donation should be regarded as morally obligatory for two reasons. First the principle of beneficence makes donation obligatory where large health gains by recipients are accrued from relatively small costs from donors, and second, fairness and particularly the wrongness of free riding obliges those who would accept blood to give, or to offer to give it. The implication for advertisements and public awareness is discussed, but perhaps the most significant implication of this analysis is to increase the emphasis of the

\footnotetext{
${ }^{1}$ A recent NHS advertisement has a boy explaining what he is not worried about. 'But I am worried about Dad smoking. I'm worried that my Dad will die.' Available at http://www.youtube.com/watch?v=BmUtR8DcMAc\&feature=related $\left(\right.$ This and all urls last accessed on $9^{\text {th }}$ August 2012)

${ }^{2}$ I do not include the obligation to pay taxes which funds, in part, other people's health care.

${ }^{3}$ Smoking, Health and Social Care (Scotland) Act 2005; Health Act 2006. Justification for the legislation was the harm principle as reported in the House of Commons Select Committee report (2005), but see also Coggon $(2009,2012)$ for a discussion of the ban applied to prisoners in Rampton Hospital where prisoners' own health was also a factor.

${ }^{4}$ See R v. Dica 3 A11 ER 593.

${ }^{5}$ The advice contained in the NHS leaflet was 'Do not go into your GP surgery or local accident and emergency department unless you are advised to do so or you are seriously ill, because you might spread the illness to others. Ask a flu friend to go out for you.' Available at http://www.direct.gov.uk/prod_consum_dg/groups/dg_digitalassets/@dg/@en/documents/digitalasset/dg_17790 3.pdf
} 
notion of obligation, challenging the predominance of individual autonomy in western bioethics.

\section{Analytical framework}

The analytical framework utilised in this paper draws upon two distinctions from the work of David Hume. First, the separation between the descriptive and the normative, the is and the ought, is maintained as far as possible, though in places the absolute distinction is difficult to maintain. Second, though not as celebrated as the is/ought distinction, Hume [1748] (2007) also distinguished practical from theoretical philosophy ${ }^{6}$. 'Theoretical' philosophy is concerned with explaining human nature, whilst the aim of practical philosophers is to explain to people what they ought to do, making

...us feel the difference between vice and virtue; they excite and regulate our sentiments; and so they can but bend our hearts to the love of probity and true honour, they think, that they have fully attained the end of all their labours.

$$
\text { Hume [1748] (2007) p.5 }
$$

In this quotation, practical philosophy is aligned more with the normative than the descriptive domain. The key feature is the difference between a reasoned philosophical exploration of the moral status of something, in our case blood donation, and the way that this is presented to those making donation choices. Theoretical philosophy, inter alia, open-mindedly selects and defends a theoretical approach, applies it to an issue, anticipates objections and considers alternatives. In contrast, A Humean practical philosopher presents arguments and conclusions seeking to persuade, to 'excite the sentiments', and 'bend the heart' of those to whom the message is directed. So in the analytical framework, the normative has at least two dimensions, the theoretical and the practical. Initially at least it is assumed that these two parts are consistent, allowing a normative position to be inferred from practical presentation, and also that a fully reasoned normative position should result in practical presentation reflecting this view. The framework applied to blood donation addresses these issues;

1. Descriptive. This is primarily an account of why people donate and why they do not, analogous to Hume's theoretical philosopher. ${ }^{7}$

2. Normative - theoretical. This consists of an account of the normative status of blood donation; whether it is required, or supererogatory or merely prudential. ${ }^{8}$

3. Normative - practical. Communicative strategy principally takes the form of media advertisements. Embedded within the advertisements are messages; some subtle and some not so subtle about the moral status of blood donation. By their nature, the advertisements are a blunt tool, addressed to all; donors, lapsed donors, and nondonors. Communication with registered donors is more individually directed, by letter, text and via social networking media, and insofar as the purpose of television

\footnotetext{
${ }^{6}$ He actually uses the terms 'easy' and 'abstruse'.

${ }^{7}$ I do not mean to suggest that individuals choose to donate or not to donate for reasons which are exclusively moral (Portmore 2008). The issue is highly complex, influenced by many social and psychological factors. The Theory of Planned Behaviour suggests that moral values are influential in determining the attitudes and subjective norms preceding an intention to donate (Ferguson et al. 2012), but it would be as significant an error to see donation exclusively in terms of moral reasons as it would be to ignore them altogether.

${ }^{8}$ Some, notably those of the Jehovah's Witness faith, regard blood donation as morally forbidden, but I do not consider that here as I am interested in blood donation within a system of therapeutic use of blood and blood products which those who regard its use in this way stand outside.
} 
advertisements is to raise awareness widely, it is most usefully directed at non-donors, offering predominantly moral reasons for action, persuasive rather than deliberative in nature.

Application of these constituent parts differs between nations but there are also similarities, coordinated by the World Health Organisation (WHO), and I will use their documentation in particular as it is consistent with, but wider than $\mathrm{UK}^{9}$ policy. To be clear; the paper concerns blood donation practice in the UK, though the analysis is transferable to some extent. The analysis is presented in two parts, each starting with what I take to be the 'official position.' First, descriptive claims are discussed and those made by the WHO are presented. It is argued that this position predominantly regards donation as altruistic, and this claim is tested and critiqued against a brief review of the empirical literature on donor motivation. Second the presented moral status of blood donation is analysed. A full normative account is not offered by blood collection agencies in the UK, and so it inferred from UK communication material which presents blood donation as an act of supererogation. An alternative account of blood donation as moral obligation is outlined, supported and illustrated by examples of communication material from blood donation in India and organ donation in the UK, both of which are plausibly transferable to blood donation.

\section{Part 1 - Description}

The 'official' position

In 2010 WHO published a framework for action with the aim of ensuring that $100 \%$ of donations are voluntary, phasing out paid and replacement donations (WHO 2010). In using this document as my primary source, it is necessary to quote at some length;

A voluntary non-remunerated blood donor gives blood, plasma or cellular components of his or her own free will and receives no payment, either in the form of cash or in kind which could be considered a substitute for money (WHO 2010 p.14).

The rationale for the emphasis on voluntary donation is primarily safety; ${ }^{10}$

Voluntary donors are recognized to be the safest donors because they are motivated by altruism and the desire to help others and by a sense of moral duty or social responsibility. They have no reasons to withhold information about their lifestyles or medical conditions that may make them unsuitable to donate blood. They are not placed under any pressure by hospital staff, family members or the community to donate blood and they entrust their blood donations to be used as needed, rather than for specific patients. The only reward they receive is personal satisfaction, self-esteem and pride (WHO 2010 p.18-19).

\footnotetext{
${ }^{9}$ There are separate organisations covering England, Scotland, Wales and Northern Ireland, though the English organisation also covers North Wales. Unless stated, references are to websites and documents from the (english) National Blood Service, part of the NHS Blood and Transplant Authority.

${ }^{10}$ This argument is derived from Titmuss' (1970) important work. Three arguments for the preference of voluntary donation are (1) Commercial supply reduces voluntary donation in the 'crowding out effect' (2) paid blood is inherently unsafe, and (3) there is a risk of exploitation and harm to poor donors who sell blood through economic necessity. Empirical evidence for these positions is scant (Farrugia et al. 2010). For a more detailed examination of Titmuss's work, see Sykora (2009), and for a critique see Rapport and Maggs (2002).
} 
Having identified voluntary donation as a consequentialist instrumental good, that is it is safest, the WHO goes on to claim altruism is what might be considered a fundamental principle;

A blood donation is a "gift of life" that cannot be valued in monetary terms. The commercialization of blood donation is in breach of the fundamental principle of altruism which voluntary blood donation enshrines (WHO 2010 p.19-20).

It is claimed that donors give for altruistic reasons and out of a sense of social responsibility;

Voluntary blood donors donate blood for altruistic reasons and receive no reward except personal satisfaction in helping to save lives and improve the health of individuals they will never meet. While they choose to donate their blood out of a sense of social responsibility, recognition of the importance of their individual donations and appreciation by the blood service and wider community help to create a sense of belonging to a special group of people. (WHO 2010 p. 92)

But there is also recognition that donors have self-interest in giving;

Voluntary blood donors themselves benefit from health education and encouragement to maintain healthy lifestyles as well as regular health checks and referral for medical care, if needed. Provided that they receive good donor care when they donate blood, they feel personal satisfaction and self-esteem which provides a sense of social engagement and belonging that is recognized and valued by the community (WHO $2010 ; 20)$.

These quotations are representative of compliant organisations. For example the UK blood transfusion service, states simply that 'All blood donors in the United Kingdom are nonremunerated volunteer donors' (UKBTS 2010), and the International Society for Blood Transfusion (ISBT) has the requirement for voluntary donation as part of its Code of Ethics, and the promotion of altruism as one if its aims (ISBT, undated). In the EU, directive 2002/98/EC of the European Parliament and of the Council required member states to encourage voluntary donation. ${ }^{11}$

The 'official' position - a critique

There is a tendency both to conflate altruism with voluntary unremunerated donation, and to present it as a simple binary choice between the unremunerated and remunerated. Both of these tendencies significantly oversimplify, and the predominance of the claim to altruism is at the expense of two further positions which are nevertheless identified in the WHO (2010) report. First that blood donation is prudential and self-interested; that donors' sense of satisfaction and the receipt of other benefits is and should be reasons to donate (Voluntary blood donors themselves benefit from health education and encouragement to maintain healthy lifestyles as well as regular health checks and referral for medical care, if needed ( $p$. 20)).

\footnotetext{
${ }^{11}$ The full text of article 20 of directive 2002/98/EC is 'Member States shall take the necessary measures to encourage voluntary and unpaid blood donations with a view to ensuring that blood and blood components are in so far as possible provided from such donations.' (see Farrell 2006 for a review of blood safety in the EU).
} 
Second, that blood donation forms part of a moral duty or social responsibility (...motivated by altruism and the desire to help others and by a sense of moral duty or social responsibility (p18)). A closer examination of this phrase reveals an important moral distinction. I will suggest that the tone of communication and the environment in which blood donation operates presents a predominant discourse of supererogation, by definition a non-obligatory act (...altruism and the desire to help others). However the second part of the sentence, preceded by the word 'and' suggests that donors also have a sense of duty or responsibility and both of these words involve the notion of obligation. The sentence appears selfcontradictory. One possible explanation is that even though blood donors are the subject of the sentence, what is meant is that some blood donors see donation as supererogatory and some see it as obligatory. But if this is the case there is plenty of untaken opportunity to make it clear, and the WHO document refers to donors throughout as a single homogenous group. Noting again the descriptive nature of the claims and the absence of an unambiguous statement of the moral status of blood donation, a more plausible explanation is that the position is muddled and contradictory.

Free will or legitimate pressure?

In the light of extensive and continuing philosophical debate about the concept, it is noteworthy that the expression 'free will' is used; it adds nothing to clarify the term 'voluntary' or the claim that donors '.... are not placed under any pressure', and may obscure them. The ISTC code of ethics (ISTC 2000) talks not of pressure but of the absence of coercion, more defensible normatively and empirically. In comparison, procedures to obtain valid consent for examination and treatment (see Department of Health [DH] for example which uses the term 'freely'), include the criterion that consent must be given 'without undue influence ${ }^{12}$ being exerted' (DH 2009 p.11). Blood donation organisations, for example the American Red Cross (undated), actively encourage the recruitment of other donors, influence from friends is given as a reason by a significant proportion of donors (Sojka and Sojka 2008), and research has been undertaken to seek the best method of encouraging donors to recruit friends (Lemmens et al. 2008). In making these observations about the language of statements made by different organisations, it is not claimed that subtle and contestable differences between the concepts influence, pressure and coercion were uppermost in the thoughts of either the writers or their intended audience, nor is it suggested that there is anything necessarily unethical about recruiting friends or allowing peer group and other pressure to influence potential donors. But there is a tension between the stated official position that blood donation is voluntary (of their own free will) and altruistic, and the recognition that undefined forms of pressure are effective, desirable and morally acceptable. Conceptually the claim to altruism appears simplistic; can it be supported by empirical research findings?

\section{A very brief review of empirical literature}

I do not offer a full discussion of the many empirical studies which assess donor behaviour and motivation. There are a number of reviews (Gillespie and Hillyer 2002, Devine et al. 2007, Masser et al. 2008, Goette et al. 2010, Bendall and Bove 2011) which discuss factors influencing behaviour. What these and other studies show is that the area is much more complex than Titmuss' altruistic model proposes, and this has been apparent for some time.

\footnotetext{
${ }^{12}$ Stewart and Lynch (2003 p. 600) report the legal case of Mrs U where undue influence requires '... something more than pressure', but it is unclear whether the DH is using the phrase in a legal or everyday sense.
} 
In 1976, for example, Condie et al. 's US study showed that social pressure and degree of free rider tendency were more important motivators than altruism, and though much of the research since then has shown higher levels of altruism in donors, there are a number of methodological problems and potential biases in the research which is undertaken largely within systems assuming altruistic donation (Buyx 2009).

Methodological problems reported by Bendall and Bove (2011) include a reliance on selfreported surveys which have the potential for social desirability bias. In contrast, an Iranian study (Maghsudlu and Nasizadeh 2011) used physicians to decide on a single predominant donating motivation based on donor interviews and found that although altruistic reasons were the biggest group at $39.1 \%$, almost as many $(38.6 \%)$ were primarily motivated by selfregarding reasons, including perceived health benefits. In this study, undertaken in a religious society, religious beliefs accounted for $11.4 \%$ of donations. In the US, Gillum and Masters (2010) hypothesised that since blood donation is perceived as an altruistic behaviour, and religions commonly advocate pro-social behaviour, there would be a correlation between religious observance and blood donation. The data, when controlled for socio-demographic factors, provided scant evidence for their hypothesis.

Steele et al. (2008) noted that studies use different definitions of altruism and measure it in different ways. In their study, instead of asking donors why they donate, a large sample (12 064) of donors recruited at blood donor sessions completed previously validated scales for altruism, empathetic concern, and social responsibility motivation. There was no significant difference in altruistic behaviour score between regular donors and those who subsequently lapsed. Older people had progressively higher scores on the altruistic measures, contrary to Maghsudlu and Nasizadeh (2011) who found that older people were more likely to donate for self-regarding reasons. Surveys often report different results than field experiments which test actual rather than declared behaviour. For example, surveys have predicted that incentives such as free cholesterol testing will increase donation rates, but this has not been confirmed experimentally (Goette et al. 2009, Stutzer and Goette 2010).

In Canada, Hupfer (2006) found that students identified more closely with an advertisement emphasising self-interest rather than altruistic messages and in one of the few UK papers, Fergusson et al. (2008) found in three studies that motivation was more benevolent than altruistic, benefitting both donor and recipient,. They claim that, though subtle, the shift in emphasis is important because self-interest has not been highlighted in recruitment campaigns. Steele et al. (2008, p.51) concluded that 'it may be time to try to appeal to selfinterest as younger donors appear to respond positively to appeals that emphasize how donating blood may help them personally'.

Research in this area has tended to be quantitative (Arnold and Lane 2011), though it is recognised that qualitative studies can be useful in examining complex behaviour. For example, In a Spanish study, Belda Suarez et al. (2004) used discourse analysis and found that donors perceived themselves to be the same as other donors and non-donors, and only a minority attributed to themselves higher awareness and kindness; an image 'fostered by the institutions responsible for promoting donation' (2004 p. 1445). It is argued that presenting messages in this way may discourage some individuals from donating.

There are a great many difficulties and challenges in researching donor motivation, but for now I simply want to make the point that the empirical evidence is contradictory and complex, and fails to support the 'official' position, which acknowledges mixed motivations but is clear that predominantly donation is and should be altruistic. 


\section{Part 2 - Normative.}

The separation between the empirical and the normative seems quite straightforward in terms of factual claims and empirical research findings, though it presents greater problems in an analysis of the moral status of blood donation. This is because there is little in the way of 'theoretical' discussion from blood collection agencies. There is, however, 'practical' presentation of the moral issues involved in blood and other tissue and organ donations, and here I analyse some aspects of these, inferring the 'theoretical' moral position from the practical presentations.

\section{The 'official position' - supererogation inferred}

The Donor Management Manual produced by DOMAIN (Donor Management in Europe ${ }^{13}$ ) states that;

'The effect on recruitment will most likely increase when the recruitment messages focuses on these factors.

- Donating blood is a good thing to do

- It generates social approval

- It can be easily accomplished: 'yes, I can be a blood donor'

(De Kort 2010 p.90)

The strategy appears without an evidence base, but the prevailing view, that blood donation is a good, generating social approval is presented. The most recent $\mathrm{UK}^{14}$ television advertisement is described below.

A man stands at the gate of a primary school waiting for his daughter. They see each other and smile. An on screen legend fades in: 'Motorway pile up. Thursday 7.52pm'

A woman is having her hair cut. In close up she is laughing. An on screen legend fades in: 'Chemotherapy starts Monday 10am'.

A man holds an infant in his arms then gently places him in a cot. In a wider angle shot it is apparent that there are two cots in the room but the second cot is empty. An on screen legend fades in: 'Liver transplant. Next Tuesday 7am'. The man wistfully plays with the mobile above the empty cot.

Narrator; Give blood and you can save someone's life. Today. Please don't leave it to someone else. Type your postcode into blood.co.uk.'

The screen fades to the NHS blood transfusion service logo over their strapline. 'Do something amazing.'

\footnotetext{
${ }^{13}$ DOMAIN is a European project that focuses on good donor management. Funded by the European Union, 18 blood organisations from 18 countries are members, including the four UK organisations.

${ }^{14}$ Available at http://www.blood.co.uk/video-audio-leaflets/tv-radio-ads/ ). This advertisement is not currently being aired but it remains available on the blood transfusion website
} 
The events that require blood transfusion are situated in the near future, and so potential donors can help the individuals by their actions. ${ }^{15}$ The everyday nature of the stories could also be designed with the aim of suggesting to the audience that they themselves might need blood. But the strap line 'Do something amazing' supports the WHO position that blood donation is altruistic and praiseworthy.

Supererogation, both as a concept within and outside normative ethical theories is underdeveloped and problematic. Urmson's seminal essay 'Saints and Heroes' recognised that the tripartite categorisation of moral acts into the forbidden, the obligatory, and the permissible is 'totally inadequate to the facts of morality' (Urmson 1969 p.60), unlike regulation which operates exclusively within these categories (Nuffield Council on Bioethics 2011). The problem, for morality if not regulation, is that the category consisting of permitted acts includes those of very different types, united simply by the properties that they are neither forbidden nor obligatory. The category includes acts that are amoral or trivially moral as well as morally good acts which exceed that demanded by obligation; the heroic act. ${ }^{16}$

Formally, the necessary properties of a supererogatory act are given by Mellema (1991 p. 3). An act is supererogatory if

1. It is an act whose performance fulfils no moral duty or obligation

2. It is an act whose performance is morally praiseworthy or meritorious

3. It is an act whose omission is not morally blameworthy.

The relationship between the term and its necessary conditions is circular (Heyd 1982) and the conditions apply to individual acts of donation more than donation in a general sense. Those whose donation requires overcoming needle phobia or forgoing something of value might, for example, be regarded as particularly praiseworthy. The principal concern here is whether blood donation is presented as morally obligatory or not and since this question forms part of an environment of supererogation the status of other elements are also of concern. There is little that addresses the normative question directly and so I propose to infer it from documents and presentations that are available and in doing so I offer two justifications for the logical sleights of hand which follow. First I return to Hume's two types of philosopher and suggest that the practical philosopher need not adhere rigidly to logical rules for his purpose is to engage with an audience to whom the rules are largely unknown. Second I can dilute my claim a little so that instead of saying that the 'official' position is that blood donation is not obligatory, I can say that this position is consistent with the evidence rather than it is demonstrated by it. So with caveats in place, and with the intention to acknowledge the sleights of hand as they occur, how do the necessary features of supererogation apply to blood donation in the UK?

The first and third conditions share the important feature of being defined in terms of what they are not rather than what they are. There is no evidence that blood donation is considered obligatory, and none either that failure to donate is blameworthy. The sleight of hand here is to accept the absence of evidence for something as evidence of the absence of something.

\footnotetext{
15 The previous campaign in the UK used celebrities who identified individuals who had helped them or a relative in the past. For example the chef Gordon Ramsay, says that 'without this man I would have died from a ruptured spleen.' (available at http://collection.europarchive.org/tna/20090605173026/http://blood.co.uk/pages/video_06.htm .

16 The webpage of the united States organisation 'Blood centres for the Pacific' is www.bloodheroes.com and the system of small rewards for donation in the form of tee shirts and restaurant vouchers is known as 'hero rewards'.
} 
However, it would be surprising if there was a clear statement of a moral position in official documents because this is not their purpose, but also because there is a clear normative tension in UK healthcare practice between any notion of obligation and the predominant moral imperative to respect and promote personal autonomy (Snelling 2012).

The second condition presents a more difficult challenge. The criterion is positively stated and so some evidence must be offered that donation is praiseworthy. I do this by offering evidence that donation is praised, and that donors are regarded as an appropriate recipient of gratitude, 'generally the mark of supererogation' (Heyd 1982 p.65). The sleight of hand here is to suggest that because an act is praised, it is praiseworthy. Gratitude can be appropriately offered for things that we are required to $\mathrm{do}^{17}$ and care is required when inferring praiseworthiness that the stated praise and gratitude do not fall within the category of gratitude offered for an obligatory act.

Gratitude is a positive emotion 'one feels when another person has intentionally given or attempted to give, one something of value' (Bartlett and deSteno 2006 p.139), and can be regarded in at least two ways (McCulloch et al. 2001). First as an appropriate response to beneficent behaviour to the extent that it might be considered that this response is required in order to avoid being thought ungrateful and second as a motivator of pro-social behaviour. Recipients of blood might be expected to feel gratitude but unlike the gratitude felt and expressed by patients for the personal care they receive from staff caring for them (Mullin 2011), or the gratitude felt towards known donors (Gill and Lowes 2008) this cannot be expressed to the individual. ${ }^{18}$ However, gratitude can be felt and expressed by recipients to the pool of donors, and this forms part of the regimen of gratitude fostered by blood donation organisations.

In the UK, a video ${ }^{19}$ posted on the webpage of the NHS Blood and Transplant Authority (NHSBT) starts by offering thanks from the organisation. A maroon background is seen on screen with a bright red heart shape in the centre, with the capitalised legend 'DEEPLY VALUED'. The commentary states: 'Thank you for coming today and for giving blood and platelets. Your contribution is important and deeply valued.' A later section shows a mother sitting with her daughter describing transfusions required following childbirth. She contrasts those who give to family members, which might be expected or required, against those who donate to strangers. She says 'I think that they're really special people', echoing the language of the WHO report. A further section shows the chief executive of the organisation talking to a donor of 140 units;

Thank you so much for coming along today. I understand you've made nearly 140 donations? That is fantastic. I'm so grateful because it's through people like yourselves (sic) that Blood and Transplant is able to save so many lives, and without you we would not be able to do our job.

During the writing of this paper, I was in communication with NHSBT. I received a helpful e mail giving requested information. At the foot of the e mail the writer thanked me for the nine donations I have made, having clearly looked me up on a database. This is an example of the role of vicarious gratitude as an intended motivator of pro-social behaviour, more likely to

\footnotetext{
${ }^{17}$ Driver (1992) argues that it is possible for an obligatory act to be considered praiseworthy, and gives some examples to show that some obligatory acts are more praiseworthy than others that are supererogatory.

18 This is in contrast to acts of donation where the recipient is known or later identified, for example living kidney donation.

${ }^{19}$ Available at http://www.blood.co.uk/video-audio-leaflets/tv-radio-ads/
} 
induce a return to Ledbury Community Centre than pointing out that nine donations in 30 years of adult life is a pretty meagre return. ${ }^{20}$ This is not a trivial point as it contributes to the general milieu of gratitude. Though the emotional gratitude expressed by recipients in the video is clearly of a different sort to that expressed by my e mail interlocutor and the Chief Executive, it would be a thin account of gratitude expression which regarded it solely in terms of a calculation to encourage repeated donation. A more plausible account is to regard the emotional response felt by recipients and the vicarious gratitude expressed as genuine responses to acts of perceived supererogation, expressed simply in the tag line of NHSBT: 'Do something amazing.'

\section{An alternative normative position.}

In this section an alternative account of the moral status of blood donation is advanced in two arguments; those from beneficence and justice. Examples of television advertisements utilising these arguments support the case that they are already familiar, though to different audiences or differently applied.

The argument from beneficence.

The principle of beneficence is familiar to healthcare professionals because of its inclusion as part of the principles based approach to bioethics (Beauchamp and Childress 2008). One perceived strength of the principles is that they can be derived from any of the major moral theories. This theoretical hedging is also a source of critique from Clouser and Gert (1990) who argue that the theoretical source of the principle of beneficence is Mill and utilitarianism. An act of beneficence is an act that helps others, but Beauchamp and Childress (2008) are clear that not all acts of beneficence are obligatory and though they take care to root their system in common morality, its purpose is to guide action within the special relationships that healthcare professionals have with those in their care. This relationship can make benevolent acts obligatory that would be supererogatory in common morality, and the same might be said for other special relationships, for example within families. As the blood donation video described earlier acknowledges, I am (ordinarily) obliged to care for and about my family in ways that I am not for my neighbour or a stranger (Smith 1993). This seems to present a problem for an attempt to define blood donation or any other beneficent act towards strangers in terms of obligation. Peter Singer has attempted to reset the normative bar in a field that is similar in many ways; charitable donation to developing countries. The formal expression of his argument is;
First premise: $\quad$ Suffering and death from lack of food, shelter and medical care are bad.

Second premise: $\quad$ If it is in your power to prevent something bad from happening, without sacrificing anything nearly as important, it is wrong not to do so.

Third premise: $\quad$ By donating to aid agencies, you can prevent suffering and death from lack of food, shelter, and medical care, without sacrificing anything nearly as important.

\footnotetext{
${ }^{20}$ And at the risk of expressing 'shallow gratitude' (Baumeister and Ilko 1995) for the modest success of writing this paper, I am happy to thank and acknowledge him in return.
} 
Conclusion: $\quad$ Therefore, if you do not donate to aid agencies you are doing something wrong.

Singer (2009 p.15-16)

The premises can be rearranged so that they apply to blood donation. The first can be restated as 'suffering and death from lack of donated blood are bad'. The second can remain as it is and the third can be similarly amended. The consequentialist calculation juxtaposes the benefit of donation against cost. In applying these premises, Singer (2009) recognises that the second is vague, but his discussion concerns a relatively small monetary sacrifice in return for a large gain in health for the poorest in developing countries. For example, he quotes a figure of approximately $\$ 250$ per life saved in a programme to prevent diarrhoea (Singer 2009 p.89).

Some advertisements from across the world are robust in presenting an opportunity to help an identified individual as morally obligatory. For example, from India, a series of advertisements produced by BBC Media Action ${ }^{21}$ includes one about a girl with thalassemia ${ }^{22}$. The advertisement does not specifically mention weighing of costs and benefits, but it obviously invokes an appeal to beneficence.

Daytime in a coffee shop. A man, about 30 sits alone reading a magazine. A girl, aged about 8 , pretty, round faced with long black hair approaches. (After the initial greeting the script is reproduced from subtitles).

Girl:

'Hello Uncle'

Man: [Smiles, puts down his magazine and turns to face the girl].'Hellooooo.'

Girl: $\quad$ 'I wanted to say thank you to you.'

Man: 'Thank you! For what?'

Girl: 'Actually, you see I have thalassemia.'

Man: [looks away, perhaps for a parent?] 'Oh.'

Girl: $\quad$ And every month an aunty or uncle like you give (sic) blood and help me.' [the camera cuts to the man's face. His smile is dropping] 'But I don't know who they are. So, I say thank you to everyone. So thank you!

Man: 'But I have never donated blood.'

Girl: $\quad$ [she wrinkles her nose] 'Hmmm'. [Pause. Then she smiles] Never mind. Next time? Bye! [she turns and walks away].

\footnotetext{
${ }^{21} \mathrm{BBC}$ Media Action is BBC's International charity. It 'is using media and communication to provide access to information and create platforms to enable some of the poorest people in the world to take part in community life, and to hold those in power accountable'

http://www.bbc.co.uk/mediaaction/what_we_do/governance_and_rights

${ }^{22}$ Available at http://www.youtube.com/watch?v=fhoPEUXFcT4
} 
Man: $\quad$ 'Bye'. [His smile fades further and he watches pensively as the girl approaches another table].

Narrator: Donate blood from the age of 18. You can save someone's life.

The screen fades to a picture of a hanging bag of blood, with the bulleted legend: 'You can donate blood every three months. Make sure it is a licensed and registered blood bank. Does not cause weakness ${ }^{23}$.'

The final scene is of the girl now being held up by the man who is standing in front of a building. They are wearing different sets of clothes, so presumably this is after a donation. The man is looking at the girl.

Girl: $\quad$ [smiling] 'Try it!'

Man: [Turns to face camera] 'It feels good'.

I am not suggesting that presentation of blood donation is this way is a central feature of the campaign. Other advertisements in the series present other perspectives, not least reassurance that blood donation does not cause weakness. The sleight of hand here is to attempt to transfer this advertisement from India to the UK, where blood transfusion services are very different. India aspires to voluntary unremunerated blood donation, but about $45 \%$ of blood for transfusion is collected from family or replacement donors (National Aids Control programme 2007), and there are a number of web-based organisations which assist patients and their relatives in their search for suitable donors ${ }^{24}$. It is estimated that $50 \%$ of blood comes from paid donations, and only $5 \%$ of voluntary donors are repeat donors (Pal et al. 2011). Ramani et al. (2007 p.259) state that '...blood-transfusion services in India are a highly-fragmented mix of competing independent and hospital-based blood-banks, serving the needs of urban populations.' The Central Drugs Standard Control Organisation website ${ }^{25}$ reports that there were 2517 licenced blood banks as of July 2011, of which 973 were government operated and 1544 were private, and Pal et al. (2011) estimated that in total, 34\% of blood banks were unlicensed. The advertisement would have been seen only by those with access to television and who had a number of options for donation, including being paid and being directly asked by the girl's relatives. This makes donation motivation and the relationship between donor and recipient significantly different than in the UK. However, the non-financial costs and benefits of donation are similar, and the arguments implied and emotions shown in the advertisement are applicable elsewhere, albeit with slight modification, and so the advertisement is worthy of analysis.

There are similarities and differences between the UK and Indian advertisements. Costs to donors are not discussed in detail, so it must be assumed that these are understood by potential donors at least in broad terms; the mild pain and inconvenience and possibly feeling slightly unwell are placed against the benefit gained by the recipient, which is always significant and frequently lifesaving. Both invite donation to save an identified person's ${ }^{26}$ life. The Indian advertisement thanks the donor (albeit mistakenly) retrospectively while the

\footnotetext{
${ }^{23}$ Thanks to Dr Sabita Menon for the translation.

${ }^{24}$ For example, see http://www.friends2support.org/

${ }^{25}$ Using data from the Ministry of health and Family Welfare. http://cdsco.nic.in/html/BloodList.html

${ }^{26}$ And of course it is no accident that the individual is an appealing child. Singer (2009) discusses studies which show that the propensity to donate money is increased when the focus is on one rather than many beneficiaries, and of course the opposite effect was well known in perhaps apocryphal quotation attributed to Stalin; 'The death of one man is a tragedy. The death of millions is a statistic.'
} 
UK one looks to future donations. In the Indian advertisement, there is identification and focus on the donor, absent from the UK advertisement which focuses exclusively on recipients. Interestingly the final words in the Indian advertisement, spoken by the man are self-regarding, a reference to well-known phenomenon that individuals feel a sense of satisfaction after donation ${ }^{27}$. The significant difference is the suggestion from India, framed in the wrinkle of an innocent nose that failure to donate, for this individual, is blameworthy, that is donation is something he ought to have done.

The very notion of supererogation is a problem for consequentialism ${ }^{28}$. If greater overall benefit is obtained by donation, then that is what we ought to do. If greater overall benefit is obtained by not donating then we ought not to do it. The supererogatory position presented by the UK advertisement, that donation is neither obligatory nor forbidden cannot easily be reconciled with consequentialist calculations, even of the everyday sort implied. Because of its everyday nature, theoretical precision in the definition of what is being maximised and how is not necessary especially as the balancing is clearly significantly asymmetrical; the asymmetry between costs and benefits also addresses a common objection to consequentialism, that it demands too much (New 1974, Mulgan 2001). Application of a broadly consequentialist approach regards blood donation as morally obligatory, recognised in the Indian if not the UK advertisement.

The argument from Justice - the wrongness of free riding

Famously, Hart (1955) and Rawls (1971) argue, from fairness, that there is an obligation to contribute to collective goods that we benefit from, that is we ought not 'free ride' on the collective actions of others. The free rider argument is invoked elsewhere within bioethics, for example in the debates between Harris (2005) and Chan and Harris (2009) in favour, and Brassington $(2007,2011)$ against, concerning obligation to support and participate in medical research, and also by John (2011) in the question of vaccination. Subtly different versions are applied in individual circumstances according to costs of contribution, and the nature and extent of benefit. An advertisement in the UK utilises the free riding problem in presenting organ donation as obligatory. ${ }^{29}$

A woman about 45 years sits comfortably on her legs in an armchair. Her teenaged son is on the sofa next to her. She looks at him and smiles then turns her attention back to the television which is out of shot and from where comes the sound of laughter. The boy is also laughing. The camera focuses on his elbow; he absentmindedly scratches it and when he removes his hand an intravenous cannula is revealed.

Commentary: If someone you love is offered a lifesaving organ, what would you do?

The boy's breathing becomes laboured and he coughs. A drip stand appears behind the sofa and a bag of intravenous fluid appears connected to the cannula. The mother watches the television apparently unaware of the transformation.

\footnotetext{
${ }^{27}$ An advertisement feature from Florida includes an interview with a doctor who suggests that blood donors have a reduced risk of cancer. The suggestion is that blood donors tend to be individuals who also consult their doctors more often, but the clear implication is a causal effect between giving blood and reduced chance of contracting cancer. Even if a more generous interpretation is allowed, this film remains a direct claim of the personal benefits of blood donation. (available at http://www.youtube.com/watch? $\mathrm{v}=8 \mathrm{MNmeLaVLdM}$ ) ${ }_{28}$ And for Kantianism (see Baron 1987).

${ }^{29}$ Available at http://www.uktransplant.org.uk/ukt/adverts_and_video/adverts_and_video.jsp
} 


\begin{abstract}
Commentary: Nothing?
The boy's hand rests on the sofa arm. Its colour changes from pink to grey. The fingers become clubbed.
\end{abstract}

\title{
Commentary: Nearly all of us would take an organ but most of us put off registering as a donor.
}

In close up, his healthily bright eye becomes, after a weary blink, bloodshot and dilated. He sinks back in the sofa rubbing his face unveiling oxygen cannulae and the paraphernalia of acute illness behind him; oxygen bottle and bleeping monitors. His mother turns to him and her smile fades.

Commentary: If you believe in organ donation, prove it.

Screen legend: Three people who need a transplant die every day.

Commentary: Register now. [on screen is a screen capture of www.organdonation.nhs.uk The cursor moves to the on screen button marked 'register now']

Organ donation provides a singular case of the free riding problem. Specifically the contribution requested by the advertisement is simply that individuals sign up to the organ donation register, but despite the provisions of the Human Tissue Act $2004,{ }^{30}$ which state that removal of organs for transplantation is lawful if the deceased gave appropriate consent (for example via the organ donation register), in practice permission is required from relatives (Institute of Innovation and Improvement 2010, and see Shaw 2012). Where consent of the patient to post mortem donation has not been given because, for example, in common with $70 \%$ of the population, the organ donor register has not been signed, he can avoid being a considered a free rider if his relatives consent to donation on his behalf. ${ }^{31}$ Alternatively if while alive the potential donor has avoided free riding by signing the register, this can be overridden by his relatives refusing donation and in this case the accusation of free riding might be more justly aimed at the relatives. Genuine free riding in this case would be restricted to those who would accept an organ but have ensured that their wish not to donate an organ is known and therefore likely to be acted upon ${ }^{32}$.

It has been argued to derive an obligation to contribute from the fact of obtaining a benefit commits the is/ought fallacy (Hardin 2007), and further standard objections to the wrongness of free riding are provided by Nozick (1974). The strongest objection is to systems enforcing contribution, but this is not the case either for blood or organ donation ${ }^{33}$. A further objection is the cost to an individual in doing his share must be outweighed by the benefits of the

\footnotetext{
${ }^{30}$ And the Human Tissue (Scotland) Act 2006.

${ }^{31}$ The free riding of the dead person is retrospective, that is the claim is that he would have accepted an organ.

${ }^{32}$ It is this latter provision which forms the minimal normative expectation in the NHS Constitution (DH 2010)

'You should ensure that those closest to you are aware of your wishes about organ donation'.

${ }^{33}$ A thin version of this would be presumed consent, currently in force in some countries and being introduced in Wales (Edwards 2010). True enforceability would mean removal of organs even in the face of refusal to consent from relatives and prior to death from the deceased. This is seldom suggested; but see Fabre (2006).
} 
actions of others. The cost/benefit ratio differs between organs, blood and other acts of donation, and benefits are stratified. Almost everyone benefits to some extent from the system of blood and organ donation. Though only recipients receive life saving benefits, these are dependent on the existence of the system of potential benefits and so they require the lesser benefit to many, and the lesser benefit to the many exists only so that greater benefit to a few recipients is possible. So when calculating benefits to the individual of the collective system, it makes no sense to consider only actual benefits to the many. The gain to individuals must be assumed to be derived from potential rather than actual benefit, and since this is significant, the cost/benefit objection is met. Nozick also objects that it is wrong to give benefits to patients and then demand payment; that is moral obligations cannot accrue in lieu of unrequested benefits. It is the case that individuals do not ask for the potential benefit of blood or organ receipt, but this is not so where individuals seek and consent to receiving organs or blood. Nozick's objections to the principle of fairness, particularly the need to avoid free riding can be answered.

Despite the singularity of its application to organ donation, it is clear that the free rider argument is used in the advertisement. Though the actual words are expressed in the hypothetical, 'if you believe in organ donation...' this is nearly everyone. The normativity is unambiguous; you ought to donate your organs. There are differences between the application of the free rider problem to organ donation and blood donation, not only in the calculations for cost and benefit but also in process, principally because of the nature of contributing an organ post mortem and the decision making processes involved. Blood donation is closer to standard accounts of free riding (Cullity 1995), complicated by stratified benefit. However, there do not appear to be any material features of the system of blood donation to distinguish it from the system of post mortem organ donation such that the free riding argument applies to the latter and not the former ${ }^{34}$. If this is the case, then it is concluded that if the need to avoid free riding is a reason to make organ donation morally obligatory, it must also make blood donation morally obligatory ${ }^{35}$.

\section{Arguments extended}

In contrast to the 'official' position, I have examined two familiar arguments that blood donation is a morally obligatory act. The first based on the duty to assist others applies to all adults, and the second, based on the moral obligation to avoid free-riding applies only to those who would accept blood. Both of these arguments rely, though in different ways, on weighing up costs and benefits. For the broadly consequentialist beneficence argument, this calculation includes benefits for others, and for the free-riding argument, in order to meet Nozick's objections, the calculation is restricted to self-regarding benefits. Both of these arguments can be applied to donation of other tissues. For beneficence, acts become less obligatory and increasingly supererogatory as the costs and risks to the donor increase. The free rider argument will not apply where the donor has no chance of ever being a recipient,

\footnotetext{
${ }^{34}$ In order to prevent free-riding Jarvis (1995) offered the 'modest proposal' that only those individuals signed up as organ donors should be eligible to receive them. A more modest version of this modest proposal, that those willing to donate should be prioritised for receipt (Eaton 1998, Trotter 2008) avoids the potential to waste organs, and has attracted, in the US, some public support (Spital 2004), and was enacted in Israel in 2008 (Lavee et al. 2010).

35 There is heightened interest in the concept of solidarity, and the arguments from beneficence and justice that I have offered could be presented within this framework. Further analysis is warranted elsewhere (see Reichlin, 2011, Prainswick and Buyx 2011).
} 
for example, sperm donation. The level of normativity can be represented on a table (see table 1, p 26-27) where acts are more obligatory at the top and more supererogatory descending down the table. The table is for illustrative purposes only and the ordering is open to challenge, but as a heuristic device it is helpful in stratifying calculations. It is consistent with the view (O'Neill 1996 p.207-208) that supererogation '....is measured by that which is required: in supererogatory action the ordinary measures of duty rather than the categories of duty are exceeded ${ }^{36}$. On this account, different acts of donation amount to different amounts of the same thing, rather than different kinds of things. The question is at what point on the scale does donation change from being obligatory to supererogatory. At present, the 'official line' appears to be drawn between post mortem organ donation and blood donation, and the argument of this paper is that it should be drawn lower, at least under blood donation, and probably a lot lower than that, and especially where the need to avoid free riding applies. ${ }^{37}$

There remains the question of the specific features and extent of the obligation to donate blood. Clearly, ought implies can, and so the obligation cannot apply to those who have received blood ${ }^{38}$ or, for example, have had a tattoo in the last four months ${ }^{39}$. The obligation is to give blood if you can, or to offer to give blood. To say that you ought to give blood is to suggest a number of distinct obligations (Zimmerman 1996). Since it is more than sixteen weeks since I last gave blood, ought I travel to Gloucester to give again, or can it wait until the mobile unit comes to my small town next month? What if on that day I cannot attend because I have promised to take my neighbour to visit her sick relative? I would say that it is clearly a moral ought rather than a non moral ought, but beyond that there is no need for further analysis here. There are many contingencies and the normativity of each potential act of donation must be evaluated in the light of its circumstances. My analysis concerns being a blood donor generally rather than considering each opportunity or act of donation ${ }^{40}$. Following Zimmerman (1996) ${ }^{41}$ the obligation is best regarded as prima facie, but in any case the importance of the arguments presented rests in their conclusion that blood donation is obligatory at all rather than in any specific sense.

Advertisements, nudges and a threat to the framework.

The most important purpose of an advertising campaign is to increase and maintain the numbers of donations. Eligible individuals can, of course, decline to give blood, but the temptation to make it clear that they are not acting in a morally acceptable way must be tempered by the possibility that this will be widely regarded as moralistic rather than moral, reducing rather than increasing donation. In this case it would be a plausible position, though apparently paradoxical, to maintain that on consequentialist grounds blood donation is

\footnotetext{
${ }^{36}$ Emphasis in original.

${ }^{37}$ In the US in 1978, a man dying from leukaemia asked a judge to compel his cousin to donate bone marrow to save his life, and in refusing the request the judge left the cousin in no doubt that his refusal was 'morally indefensible' (Steinbock 1980). Regarding the act of donation of bone marrow as an obligation presents some difficulties, not least because, as in this case, of the complications of the Rule of Rescue (McKie and Richardson 2003) and family obligations.

${ }^{38}$ The full list is available at http://www.blood.co.uk/can-i-give-blood/who-cant-give-blood/

${ }^{39}$ It would be going too far to suggest that you ought not have a tattoo because it interferes with your opportunity to donate.

40 This analysis will differ for different acts of donation. Signing up to the bone marrow donation register will be of little value if I find a trivial reason not donate on the one occasion in 20 years when I am asked to make good on my intentions.

${ }^{41}$ Who followed W.D. Ross (1930).
} 
morally obligatory, but that advertisements should continue to present it as supererogatory. This would present some problems for the analytical framework utilised in this paper

First, the assumption that there is, or should be, consistency between the theoretical and practical expression of the moral status of blood donation is challenged questioning the normative inferred from the descriptive. However a critique of this method and findings does not invalidate the 'alternative' moral status of blood donation which can stand outside the framework if necessary. A more serious critique would be that focussing on the most effective presentation renders an analysis of moral status of donation redundant. Nagel (1970) perceived ethics as a branch of psychology, but even if the relative importance of moral philosophy was to retreat in the face of insights from psychology and neuroscience, it does not follow that philosophical analysis is of no value at all.

In other fields, negative marketing has been found more likely to result in self-protection and inaction (for example, Brennan and Binney 2010) and studies cited earlier suggested that advertisements should emphasise self-regarding rather than other regarding reasons to donate. The role of psychological framing is influential; popularised by Thaler and Sunstein's (2009) book, 'Nudge' which has become 'an instant classic' (Coggon 2012 p.12), Behavioural Insight has become an important part of UK public health policy ${ }^{42}$ (Cabinet office 2010, 2011), claiming some success in, for example, required choice for organ donation, and reducing missed appointments by simple behavioural interventions (Cabinet Office 2011, Martin et al. 2012). ${ }^{43}$ Despite the claims made for framing, a recent review by the Cochrane Library (Akl et al. 2011) found very little evidence of its effectiveness.

Further research into the practical applications of framing and nudging applied to blood and organ donation may yield interesting and useful insights. However, though important, the significance of TV advertisements and other public presentation is not restricted to the narrow matter of procuring the most blood. ${ }^{44}$ Placed in the wider context of the role of autonomy and choice related to health enhancing and threatening behaviour, highlighting the normativity of blood donation could serve to emphasise the general notion that health is a legitimate matter for public concern, and that other-regarding considerations in relation to others' health as well as our own result in a range not only of choices but of obligations. As I have shown, presenting donation in this light is already a feature of blood donation advertisements overseas, and organ donation advertisements from the UK.

\section{Conclusion}

Western bioethics reveres personal autonomy and its facilitation above all else. However, if the concept of responsibility for health is to be meaningfully operationalized in an age of alarming increase of lifestyle induced ill health, the notion and extent of obligation must be

\footnotetext{
${ }^{42}$ According to the Cabinet Office (2011 p.4) the cabinet office team has 'strong links' to Professor Richard Thaler, co-author of 'Nudge'.

${ }^{43}$ There are however, differences in the stated motivations between its theory and practice. The UK Government's aim is to find 'intelligent ways to encourage, support and enable people to make better choices for themselves' (Cabinet Office 2011 p.9), which sits uneasily with Thaler and Sunstein's (2008 p.40) view that 'framing works because people tend to be somewhat mindless, passive decision makers.'

${ }^{44}$ There are seldom media stories explaining that treatment has to be curtailed because of insufficient supply, so it is assumed that despite occasional pressure the current system, including the advertisements, meets the needs placed upon it, though blood donation organisations would doubtless prefer the problem of having too many donors rather than too few (Carter et al. 2011). As I write this there is some concern about the potential for shortages over the olympic summer resulting in more targeted approaches to individual donors.
} 
defined, justified and defended. This remains problematic for self-regarding reasons for action, more so for normative consideration of other-regarding acts which are seen as mere supplicants at the feet of the personal autonomy god. I have argued that individuals have other-regarding responsibilities for other's health, where the cost is small and the benefit large, and where the imperative to avoid moral free riding is clear. Blood donation is a paradigm example of pro-social behaviour which has hitherto been regarded and presented as altruistic and supererogatory. However, application of arguments from beneficence and justice challenge this established moral status, recognised in part by somewhat inconsistent communicative strategies. Offering blood for donation for the benefit of others is a moral obligation, and in the absence of evidence of an unintended deleterious effect, this should be made visible and unambiguous in public discussions, documents and advertisements.

Acknowledgement.

I gratefully acknowledge funding for doctoral study from the University of the West of England and Dr John Coggon and Professor Margot Brazier for supervision at the University of Manchester. 


\section{References}

Akl, E.A., Oxman, A.D. Herrin, J., Vist, G.E. Terrenato, I., Sperati, F., Costiniuk, C., Blank, D. Schünemann, H. (2011) Framing of health information messages (Review) The Cochrane Library, December 2011.

American Red Cross (undated) FAQs about donating blood. [on line] http://www.redcrossblood.org/hosting-blood-drive/ultimate-guide-hosting-blooddrive/recruitment-strategies-tips (last accessed 14 ${ }^{\text {th }}$ March 2012).

Arnold, E., and Lane, S. (2011). Qualitative research in transfusion medicine. Transfusion Medicine 21, 5, 291-300.

Baron, M (1987) Kantian ethics and supererogation. The Journal of Philosophy 84 (5) $237-262$.

Bartlett, M.Y., DeSteno, D (2006) Gratitude and Prosocial behaviour : Helping when it costs you. Psychological Science 17, 319 - 325.

Beauchamp, T.L., and Childress, J.F. (2008) Principles of Biomedical Ethics (sixth edition) Oxford: Oxford University Press.

Baumeister, R.F., Ilko, S.A. (1995) Shallow gratitude: Public and private acknowledgements of external help in accounts of success. Basic and Applied Social Psychology 16 (1 \& 2) 191 - 209.

Bednall, T.C., Bove, L.L. (2011) Donating blood: a meta-analytic review of self-reported motivators and deterrents. Transfusion Medicine Reviews 25 (4) 317-334.

Belda Suarez, I.M., Fernandez-Montoya A., Rodriguez Fernandez, A., Lopez-Berrio, A., Cillero-Penuela (2004) How regular blood donors explain their behaviour. Transfusion 44, 1441 - 1446.

Bennett, R. (2007) Should we criminalise HIV transmission? In Erin, C.A., Ost, S. (Eds) (2007) The Criminal Justice System and Health Care. Oxford: Oxford University Press. Chapter 13, 225-236.

Brassington, I (2007) John Harris' argument for a duty to research. Bioethics 21 (3) 160 168.

Brassington, I (2011) Defending the duty to research? Bioethics 25 (1) $21-26$.

Brennan, L., and Binney, W. (2010) Fear, guilt, and shame appeals in social marketing. Journal of Business Research 63, 140 - 146.

Buyx, A (2009) Blood donation, payment and non-cash incentives: Classical questions drawing renewed interest. Transfusion Medicine and Hemotherapy 36, 329- 339.

Cabinet Office (2010) Applying Behavioural Insight to Health. London: Cabinet Office Behavioural Insights Team.

Cabinet Office (2011) Behavioural Insights Team Annual update 2010-11. London: Cabinet Office Behavioural Insights Team. 
Carter, M.C., Wilson, J., Redpath, G.S., Hayes, P., Mitchell, C (2011) Donor recruitment in the $21^{\text {st }}$ Century: challenges and lessons learnt in the first decade. Transfusion and Apheresis Science 45, 31-43.

Chan, S., and Harris, J (2009) free riders and pious sons - why scientific research remains obligatory. Bioethics 23 (3) 161 - 171.

Clouser, K.D and Gert, B (1990) A critique of principlism. The Journal of medicine and philosophy 15 (2) $219-236$.

Condie, S.J., warner, W.K. Gillman, D.C. (1976) Getting blood from collective turnips: Volunteer Donation in Mass Blood Drives. Journal of Applied Psychology 61(3) $290-294$.

Coggon, J. (2009) Public health, responsibility and English law: are there such things as no smoke without ire or needless clean needles? Medical Law Review, 17, 127139.

Coggon, J. (2012) What Makes Health Public? A Critical Evaluation of Moral, legal and Political Claims in Public Health. Cambridge: Cambridge University Press.

Cullity, G (1995) Moral Free Riding. Philosophy \& Public Affairs 14, 1, 3-34.

De Kort, W (Ed) (2010) Donor Management Manual. Nijmegen; Domain Project. [on line] http://www.domaine-europe.eu/ManualPDF/tabid/115/Default.aspx (last accessed 14th March 2012).

Department of Health (2009) Reference guide to consent for examination or treatment. Second edition. London: Department of Health.

Department of Health (2010) The NHS Constitution. London: Department of Health.

Devine, D., Goldman, M., Engelfriet, C.P., Reesink, H.W., Hetherington, C., Hall, S. et al. (2007) Donor recruitment research. Vox Sanguinis, 93, 250 - 259.

Driver, J (1992) The Suberogatory. Australasian Journal of Philosophy 70, 3, 286-295.

Eaton, S, (1998) The subtle politics of organ donation; a proposal. Journal of Medical Ethics 26; 166 - 170.

Edwards, S.D. (2008) Discussion document; Introduction of an opt out (presumed consent) system in the context of Organ Transplantation. Cardiff: Welsh Assembly Government. [on line] http://wales.gov.uk/dhss/publications/health/guidance/discussion/discussionconse nte.pdf;jsessionid=xTPHTTZL2C1XgCJC1GNxKQvsKyBRrb3J21QqQJXhWw6p LxQrcfhV!1374374152?lang=en (last accessed $14^{\text {th }}$ March 2012).

Fabre, C. (2006) Whose body is it anyway? Oxford: Oxford University Press.

Farrell, A-M (2006) Is the gift still good? Examining the politics and regulation of blood safety in the European Union. Medical Law Review 14, 155 - 179.

Farrugia, A., Penrod, J., Bult, J.M. Payment, compensation and replacement - the ethics and motivation of dlood and plasma donation. Vox Sanguinis 99, $202-211$. 
Ferguson, E., Farrell, K., Lawrence, C. (2008) Blood donation is an act of benevolence rather than altruism. Health Psychology 27 (3) 327 - 336.

Ferguson, E., Atsma, F. de Kort, W., Veldhuizen, I (2012) Exploring the pattern of blood donor beliefs in first time, novice, and experienced donors: differentiating reluctant altruism, pure altruism, impure altruism and warm glow. Transfusion 52 (2) 343-355.

Ferguson , P.R. (2011) 'Smoke gets in your eyes...': the criminalisation of smoking in enclosed public places, the harm principle and the limits of the criminal sanction, Legal Studies 31:2, 259-278.

Gill, P., Lowes L (2008) Gift exchange and organ donation: Donor and recipient experiences of live related kidney transplantation. International Journal of Nursing Studies 45 1607-1617.

Gillespie, T.W., and Hillyer C.D. (2002) Blood Donors and factors impacting the blood donation decision. Transfusion Medicine Reviews 16 (2) 115 - 130.

Gillum, R.F., and Masters, K.S. (2010) Religiousness and blood donation; findings from a national survey. Journal of Health Psychology 15 (2) 163 - 172.

Goette, L., Stutzer, A., Yavuzcan, G., Frey, B.M. (2009) Free cholesterol testing as a motivation device in blood donations: evidence from field experiments. Transfusion 49, $524-531$.

Goette, L., Stutzer, A, Frey, B.M. (2010) Prosocial motivation and blood donations: a survey of the empirical literature. Transfusion Medicine and Hemotherapy 37, 149 -154 .

Hardin, R. (2007) David Hume: Moral and Political Theorist. Oxford: Oxford University Press.

Harris, J. (2005) Scientific research is a moral duty. Journal of Medical Ethics 31, 242 248.

Hart, H.L.A. (1955) Are there any natural rights? The Philosophical Review 64(2)175191.

Heyd, D. (1982) Supererogation. Cambridge: Cambridge University Press.

House of Commons Health Committee (2005) Smoking in Public Places; First report of session 2005 - 2006. London; The Stationary Office limited. [on line]. http://www.publications.parliament.uk/pa/cm200506/cmselect/cmhealth/485/485. pdf (last accessed 14th March 2012).

Hume, D. (1748 [2007]) An Enquiry Concerning Human Understanding. Oxford; Oxford University Press.

Hupfer, M.E. (2006) Helping me, helping you: self-referencing and gender roles in donor advertising. Transfusion 46, 996-1005. 
International Society of Blood Transfusion (undated) aims and objectives. [on line] http://www.isbtweb.org/about-isbt/isbt-partners/ifbdo/ last accessed $14^{\text {th }}$ March 2012.

International Society of Blood Transfusion (2000) A code of ethics for blood donation and transfusion. Amsterdam; International Society of Blood Transfusion.

Institute of Innovation and Improvement (2010) Consent / Authorisation for Donation after Brain-stem Death. [on line] http://www.organdonation.nhs.uk/ukt/about_us/professional_development_progra mme/pdf/Consent_and_Authorisation.pdf (1Ast accessed 14 ${ }^{\text {th }}$ March 2012).

Jarvis, R. (1995) Join the club: a modest proposal to increase the availability of donor organs. Journal of Medical Ethics 21; 199 - 204.

John, S (2011) Expert testimony and epistemological free-riding: The MMR controversy. The Philosophical Quarterly 61, 244, 496- 517.

Lavee, J., Ashkenazi, T., Gurnham, G., Steinberg, D (2010) A new law for allocation of donor organs in Israel. The Lancet 375, 1131-1133.

Lemmens, K.P.H., Abraham, C., Ruiter, R.A.C., Veldhuizen, I.J.T., Bos, A.E.R. Schaalma, H.P. (2008) Identifying blood donors willing to help with recruitment Vox Sanguinis 95, 211-217.

Maghsudlu, M., Nasizadeh, S. (2011) Iranian blood donors' motivations and their influencing factors. Transfusion Medicine 21, 247 - 252.

Masser, B.M., White, K.M., Hyde, M.K., Terry, D.J. (2008) The psychology of blood donation: Current research and future directions. Transfusion Medicine Reviews 22 93) $215-233$.

Martin, S.J., Bassi, S., rees, R.D. (2012) Commitments, norms and custard creams - a social influence approach to reducing did not attends (DNAs). Journal of the Royal Society of Medicine.105, $3101-104$.

McCulloch, M.E., Kilpatrick, S.D., Emmons, R.A. Larson, D.B. (2001) Is gratitude a moral affect? Psychological Bulletin 127, 2, 249 - 266.

McKie, J., and Richardson, J. (2003) The Rule of rescue. Social Science \& Medicine 56 2407-2419.

Mellema, G (1991) Beyond the Call of Duty. Albany: State University of New York Press.

Mulgan, T. (2001) The Demands of Consequentialism. Oxford: Oxford University Press.

Mullin, A. (2011) Gratitude and caring labour. Ethics and Social Welfare 5, 2, 110 - 122.

Nagel, T. (1970) The Possibility of Altruism. Princeton: Princeton University Press.

National Aids Control Programme (2007) Voluntary Blood Donation Programme. New Delhi: Ministry of Health and family Welfare, Government of India.

New, C. (1974). Saints, heroes and Utilitarians. Philosophy, 49, 179-189. 
Nozick, R. (1974) Anarchy, State and Utopia. New York: Basic Books.

Nuffield Council on Bioethics (2011) Human bodies: donation for medicine and research. London: Nuffield Council of Bioethics.

O’Neill, O. (1996) Towards justice and virtue: a constructive account of practical reasoning. Cambridge: Cambridge University Press.

Pal, R., Kar, S., Akhtar, F., Pal, S. (2011) The quest for an Indian blood law as of blood transfusion services regulatory framework. Asian Journal of Transfusion Science. 5 (2) $171-174$.

Portmore, D.W. (2008) Are moral reasons morally overriding? Ethical Theory and Moral Practice. 11. 369-388.

Prainswick, B., and Buyx, A. (2011) Solidarity : Reflections on an emerging concept in bioethics. London: Nuffield Council on Bioethics.

Ramani, K.V., Mavalankar, D.V., and Govil, D. (2009) Study of Blood-transfusion Services in Maharashtra and Gujarat States, India. Journal of Health Population and Nutrition 27 (2) 259-270.

Rapport, F.L., and Maggs, C.J. (2002). Titmuss and the gift relationship: altruism revisited. Journal of Advanced Nursing 40 (5) 495-503.

Rawls, J. (1971) A Theory of Justice. Oxford: Oxford University Press.

Reichlin, M. (2011) The role of solidarity in social responsibility for health. Medicine Health Care and Philosophy. 14, 365-370.

Ross, W.D. (1930 [2002]) The Right and the Good. Oxford: Clarenden Press.

Shaw, D. (2012) We should not let families stop organ donation from their dead relatives, British Medical Journal. 345, e5275.

Singer, P. (2009) The Life You can Save. London: Picador.

Smith, P. (1993) Family responsibility and the nature of obligation. In Meyers, D.T., Kipnis, K., Murphy, C.F. (Eds)(1993) Kindred Matters Ithaca: Cornell University Press.

Snelling, P.C. (2012) Saying something interesting about responsibility for health. Nursing Philosophy 13, $161-178$.

Sojka, B.N. and Sojka, P. (2008) The blood donation experience: self-reported motives and obstacles for donating blood. Vox Sanguinis 94, 56-63.

Spital, A. (2004) Should people who commit themselves to organ donation be granted preferred status to receive organ transplants? Clinical Transplantation 19; 269 272.

Steele, W.R., Schreiber, G.B., Guiltinan, A., Nass, C., Glynn. S.A., Wright, D.J., et al.. (2008) The role of altruistic behaviour, empathetic concern, and social responsibility motivation in blood donation behaviour. Transfusion. 48; 43-54. 
Steinbock, R. (1980) Unrelated volunteers as bone marrow donors. Hastings Centre Report 10 (1) $11-20$.

Stewart, C. and Lynch, A (2003) Undue influence, consent and medical treatment. Journal of the Royal Society of Medicine, 96, 598-601.

Stutzer, A. and Goette, L. (2010) Blood donor motivation. What is ethical? What works? ISBT Science Series 5, 244-248.

Sykora, P. (2009). Altruism in Medical Donations Reconsidered: The Reciprocity Approach. In Steimann, M., Sykora, P, Wiesling, U (Eds) Altruism Reconsidered: Exploring New approaches to Property in Human Tissue. Farnham: Ashgate Publishing. Chapter 2, pp 13-50.

Thaler, R.H. and Sunstein, C.R. Nudge: Improving Decisions about health wealth and happiness. London: Penguin.

Titmuss, R. (1970) The Gift Relationship; from human blood to social policy. London: George Allen and Unwin.

Trotter G (2008) Preferred allocation for registered organ donors. Transplantation Reviews 22, 158 - 162.

United Kingdom Blood Transfusion Service (2010) Guidelines for Blood Transfusion in the UK.[on line] http://www.transfusionguidelines.org (last accessed $14^{\text {th }}$ March 2012).

Urmson, J.O. (1958) Saints and Heroes. In Feinburg, J (Ed) (1969) Moral Concepts. London: Oxford University Press. Chapter 5, p $60-73$.

World Health Organisation (2010) Towards 100\% voluntary blood donation: a global framework for action. Geneva: World Health Organisation.

Zimmerman, M.J. (1996) The concept of moral obligation. Cambridge: Cambridge University Press. 
Table 1. Costs and benefits of acts of tissue donation

\begin{tabular}{|c|c|c|c|c|}
\hline Act & Costs to donor & Benefits to recipient & $\begin{array}{l}\text { Free rider } \\
\text { argument? }\end{array}$ & Notes \\
\hline $\begin{array}{l}\text { Samples for } \\
\text { research }\end{array}$ & $\begin{array}{l}\text { Very little - time, perhaps or minor tissue } \\
\text { extraction. Or perhaps no cost at all. }\end{array}$ & $\begin{array}{l}\text { New drugs and treatments improve } \\
\text { treatments }\end{array}$ & yes & \\
\hline $\begin{array}{l}\text { Cadaveric organ } \\
\text { donation }\end{array}$ & $\begin{array}{l}\text { Thinking about mortality. } \\
10 \text { minutes to sign register with regular } \\
\text { updating, and discussion with relatives. }\end{array}$ & $\begin{array}{l}\text { Organ donation saves (heart) and } \\
\text { improves (cornea) many identified lives. }\end{array}$ & $\begin{array}{l}\text { Yes. Presented in } \\
\text { advertisements }\end{array}$ & $\begin{array}{l}17,751,795 \text { people on } \\
\text { organ donation register. }^{\text {a }} \\
\text { Official NHS position - } \\
\text { obligatory. Consent rate } \\
65 \%{ }^{\text {b }}\end{array}$ \\
\hline Blood donation & $\begin{array}{l}\text { About an hour of donors time } \\
\text { Slight pain around needle site } \\
\text { Occasional transient feeling slightly unwell }\end{array}$ & $\begin{array}{l}\text { Many lives saved and morbidity } \\
\text { improved } \\
\text { Wide indirect benefit from knowing that } \\
\text { blood is available if needed }\end{array}$ & Yes. & $\begin{array}{l}1.4 \mathrm{~m} \text { donors in } 2010^{\mathrm{c}} \\
2 \mathrm{~m} \text { units donated. }\end{array}$ \\
\hline Platelet donation & $\begin{array}{l}\text { More frequent donation than blood. Requires } \\
\text { connection to apheresis machine. Takes } \\
\text { approximately } 90 \text { minutes. }\end{array}$ & Lifesaving and life prolonging & Yes & 14500 platelet donors $^{\mathrm{d}}$ \\
\hline $\begin{array}{l}\text { Bone marrow } \\
\text { donation (stem } \\
\text { cell donation) }\end{array}$ & $\begin{array}{l}\text { Registering as a donor } \\
\text { If required, daily injections for five days } \\
\text { followed by collection via blood. A few days } \\
\text { time needed for donation. Occasionally a } \\
\text { minor procedure under general anaesthetic }\end{array}$ & $\begin{array}{l}\text { To an individual recipient - chance of } \\
\text { cure from an otherwise fatal disease. }\end{array}$ & Yes. & $\begin{array}{l}\text { More than } 770000 \text { on } \\
\text { registers. } 750 \text { donations } \\
\text { to unrelated recipients in } \\
\text { 2009. }\end{array}$ \\
\hline Egg donation & $\begin{array}{l}\text { Minor procedure involving general } \\
\text { anaesthetic, some pain }\end{array}$ & $\begin{array}{l}\text { Potentially life changing to childless } \\
\text { couples }\end{array}$ & No & 1258 donors in $2010^{f}$ \\
\hline Sperm donation & $\begin{array}{l}\text { Weekly visits to clinics, tests, interviews } \\
\text { Possibility of offspring contact after } 18 \text { years }\end{array}$ & $\begin{array}{l}\text { Potentially life changing to childless } \\
\text { couples }\end{array}$ & No & 480 donors in $2010^{\mathrm{g}}$ \\
\hline $\begin{array}{l}\text { Live organ } \\
\text { donation }\end{array}$ & $\begin{array}{l}\text { Major operation } \\
\text { Possibility of needing both kidneys later (e.g. } \\
\text { trauma to remaining kidney). } \\
\text { Risk of death in operation ( } 1 \text { in } 3000 \text { for } \\
\text { kidney donation }^{\text {h }} \text { ) }\end{array}$ & $\begin{array}{l}\text { Potentially lifesaving to identified } \\
\text { recipient }\end{array}$ & $\begin{array}{l}\text { Not at present. A } \\
\text { narrower } \\
\text { argument from } \\
\text { reciprocity may } \\
\text { apply. }\end{array}$ & $\begin{array}{l}1045 \text { living donations in } \\
\text { 2010. } 60 \text { altruistic } \\
\text { donations (including } \\
\text { paired donations) }\end{array}$ \\
\hline
\end{tabular}

Notes. 
This table is for illustrative purposes only. It has not included benefits to donors, such as the 'warm glow' of altruism. Donation of bone marrow and live organs to relatives may have special value to donors.

${ }^{a}$ March 2011 figure http://www.organdonation.nhs.uk/ukt/statistics/statistics.asp

${ }^{\mathrm{b}} \mathrm{http}: / /$ www.nhsbt.nhs.uk/annualreview/pdf/nhsbt_annual_review_2010-2011.pdf

${ }^{\mathrm{c}}$ http://www.nhsbt.nhs.uk/annualreview/blood_components/

d June 2012. Personal communication from Gareth Humphries, NHSBT.

${ }^{\mathrm{e}} \mathrm{http}: / /$ www.nhsbt.nhs.uk/pdf/uk_stem_cell_strategic_forum_report.pdf Existing registers are to be amalgamated into a single register managed by the Antony Nolan trust

${ }^{\mathrm{f}}$ http://www.hfea.gov.uk/3411.html includes both those who donate all their eggs in a treatment cycle (non-patient egg donors) and those who share their eggs with up to two recipients (egg share donors)

g http://www.hfea.gov.uk/3411.htm

${ }^{\mathrm{h}} \mathrm{http}$ ://www.organdonation.nhs.uk/ukt/how to become a donor/living kidney donation/pdf/living kidney donation.pdf

i http://www.nhsbt.nhs.uk/annualreview/organ_donation transplantation/focus living_donation.asp 